\title{
МЕТОДИКА ПРОВЕДЕННЯ ЗАНЯТЬ 3 ФАНТОМНИМ МОДЕЛЮВАННЯМ НА БАЗОВОМУ ЕТАПІ ВИВЧЕННЯ ГІНЕКОЛОГІЇ
}

\author{
Л. М. Маланчук, Л. І. Романчук, І. М. Маланчин, В. М. Мартинюк \\ ДВНЗ “Тернопільський державний медичний університет імені І. Я. Горбачевського \\ мОЗ України”

\section{THE TECHNIQUE OF TEACHING LESSONS WITH PHANTOM SIMULATION AT A BASIC STAGE OF GYNECOLOGY LEARNING} \\ L. M. Malanchuk, L. I. Romanchuk, I. M. Malanchyn, V. M. Martyniuk \\ I. Horbachevsky Ternopil State Medical University
}

\begin{abstract}
Підготовка висококваліфікованих фахівців є основним завданням сучасної медицини. В умовах інтеграції системи вищої освіти України у європейське та світове освітнє співтовариство вимагає інноваційних підходів у процесі формування професійної майстерності. У статті висвітлено особливості проведення занять на базовому етапі вивчення гінекології з використанням симуляційних манекенів. Обґрунтована методика фантомного навчання як така, що максимально сприяє формуванню компетентнісного підходу до практичних складових освіти майбутнього лікаря. Визначена роль викладача, вимоги, які покладаються на нього як лідера та організатора навчального процесу.
\end{abstract}

Preparation of highly qualified specialists is the main objective of modern medicine. In terms of integration of the higher education system of Ukraine into European and world educational community requires innovative approaches in the process of formation of professional skills. In the article the peculiarities of training at the basic stage of learning gynecology using simulation mannequins are highlighted. The technique of the phantom study as such that maximally promotes the formation of competence approach to the practical component of education of future doctors is grounded. The role of the teacher, the requirements assigned to him as the leader and organizer of the educational process is considered.

Вступ. Підготовка майбутнього лікаря передбачає оволодіння сумою базових практичних навиків, які забезпечать можливість ефективної роботи з пацієнтами. Поступ на шляху модернізації професійної освіти вимагає трансформації знань та вмінь студента у ранг тактичних освітніх одиниць, що формують компетентнісний підхід до практичних складових освіти майбутнього лікаря та забезпечують високу конкурентоспроможність фахівця нового рівня [1].

За сучасних умов типовою є проблема, коли студенти, що мають належний обсяг теоретичних знань, зазнають непереборних труднощів у використанні їх для вирішення конкретних завдань та реальних медичних ситуацій через брак практичних умінь. Саме цю проблему вирішує використання симуляційних технологій, що широко запроваджені у світову освітню практику.

Основна частина. Найпростіші симулятори відомі віддавна. Першим запровадив навчання акушерок на виготовлених за власними проектами фантомах і муляжах кісткового таза ще славетний уродженець Полтавщини Нестор Максимович-Амбодик у Петербурзькій повивальній школі у 1784 році. У Франції наприкінці XVIII століття була відома "машина мадам du Coudrey” - акушерки, що використовувала для навчання майбутніх повитух та лікарів-акушерів комплекс пошитих з лляної тканини натурального кольору фантомів, які максимально імітували матку зі зв'язками, родові шляхи, плаценту з оболонками, плід з кінцівками, що згиналися і дозволяли моделювати будь-яке його положення та акушерську ситуацію. Акушерська “машина", за словами самої мадам du Coudrey, - це було все, “що треба було сказати очам і рукам” студентів, а ії девізом: “Практика, практика, практика” [5].

Сучасні технології дозволили симуляційному навчанню сягнути від звичайних муляжів, анатомічних моделей та простих фантомів частини людського тіла до комп’ютеризованих манекенів

() Л. М. Маланчук, Л. І. Романчук, І. М. Маланчин, В. М. Мартинюк 
та тренажерів - фігур та пристроїв, що дозволяють штучно відтворювати ситуації для формування окремих навичок та умінь чи цілого їх комплексу.

Останні десятиліття принесли в медичну освіту зміни, що відповідають світовим тенденціям, в основі яких - пріоритети безпеки пацієнта з урахуванням його прав за умов введення страхової медицини. Світовий альянс за безпеку пацієнтів та В0O3 вимагають від вищої медичної школи створення безпечного та надійного освітнього середовища для опрацювання клінічних умінь [2, 4]. Особливо гостро стоїть це питання для кафедр акушерства і гінекології, оскільки стає дедалі важче отримати згоду пацієнтки на гінекологічне обстеження - із цілком зрозумілих етичних та юридичних причин. 3 іншого боку, засвоєння та відпрацювання базових навиків гінекологічного огляду, як-от огляду шийки матки в дзеркалах, бімануального дослідження, взяття мазків для різних видів досліджень може і повинно бути здійснене на догоспітальному етапі в умовах навчальної кімнати з використанням фантомного моделювання, лише після цього можливий початок занять вже підготовленого теоретично і практично студента “біля ліжка хворого”.

Симуляційне навчання є методом універсальним і водночас інтегративним, оскільки є різним за суттю та методами при використанні у роботі зі студентами IV i V курсів, які щойно розпочинають вивчення акушерства та гінекології і потребують первинного формування базових умінь та навичок, зі студентами VI курсу, які вже володіють достатнім обсягом умінь і можуть використати їх для вирішення практичних завдань та складних діагностичних ситуацій, а також потребують відпрацювання навичок надання допомоги при невідкладних станах, 3 лікарями-інтернами та практичними лікарями, що мають великий досвід роботи і працюють над удосконаленням конкретних змодельованих ситуацій 3 метою напрацювання автоматизму адекватного реагування на них.

Робота в симуляційному центрі зі студентами базового рівня потребує глибокого розуміння сутності процесу формування умінь та навиків, в якому можна виділити 4 етапи:

1. Підготовчий. Формується закладення теоретичної програми навику, що полягає у визначенні мети, техніки процесу та послідовності дій. 3 метою оптимізації та уніфікації техніки кожного практичного навику кафедрою акушерства і гінекології № 1 ТДМУ розроблений алгоритм дій, якого дотримуються і викладачі, і студенти, що необхідно як у процесі вивчення, так і під час проведення контрольних клінічних практичних іспитів.

2. Аналітичний. Кожен рух виконується окремо 3 метою аналізу його доцільності, перцептивних особливостей, розрахунку напряму та сили, послідовності та взаємопов’язаності. Результатом аналізу є відповідь на запитання: “Як? Чому? Навіщо?”

3. Синтетичний. Окремі елементи об’єднуються в одне ціле, комплекс рухів утворює одне сенсорне поле. На цьому етапі надважливим є розуміння необхідності послідовних дій для досягнення результату. Результатом синтезу є відповідь на запитання: “Що отримали?”

4. Вироблення автоматизму. Після помилок та зайвих рухів, які є незмінними супутниками процесу засвоєння нового, змінюється темп і ритм дій, що виконуються, вони плавно переходять одна в одну. Зникає необхідність зорового контролю кожної дії, він переходить на рівень кінестетики, що є основним у практиці гінеколога.

Найважливішим моментом у формуванні навику $€$ його багаторазове повторення, що цілком реальне в умовах симуляційного центру.

Формою вироблення навиків на базовому етапі навчання $є$ тренінг [3]. Наступним етапом може бути симуляційна програма, що передбачає виконання засвоєного навику в умовах зміни вихідних даних чи моделюванні ускладнень.

Провідна роль у процесі симуляційного навчання належить викладачу. Його основними завданнями є:

- проведення брифінгу - у формі постановки мети і програми дій;

- створення атмосфери позитивної психологічної мотивації, що сприяє підвищенню ефективності засвоєння і виживання знань та вмінь;

- подача достовірної інформації та демонстрація правильного виконання навиків відповідно до алгоритму;

- координація дій кожного студента і групи в цілому;

- контроль правильності виконання навиків кожним студентом, висловлення зауважень у коректній та доброзичливій формі;

- проведення тренінгової частини заняття із багаторазовим повторенням навиків аж до досягнення рівня автоматизму та аналітичної оцінки результатів;

- переведення заняття з форми тренінгу у форму симуляційної програми шляхом ускладнення вихідних даних та змін обставин дослідження;

- проведення дебрифінгу з аналізом проблем, що виникли в процесі роботи, у формі “позитивної критики”. 
У Тернопільському державному медичному університеті ім. І. Я. Горбачевського у 2016 році створено центр симуляційного навчання, в якому діють гінекологічний та пологовий зали, обладнані новітніми високотехнологічними манекенами, що дають можливість вивести практичне навчання студентів на новий рівень.

У гінекологічному залі викладачі нашої кафедри проводять заняття з гінекології зі студентами IV курсу за темами "Методи обстеження гінекологічних хворих” та “Доброякісні пухлини жіночих статевих органів. Фонові та передракові захворювання”. Сучасні фантоми дозволяють оволодіти навиками огляду шийки матки в дзеркалах та бімануального гінекологічного обстеження, даючи тактильні відчуття, максимально наближені до відчуттів лікаря при реальному обстеженні пацієнтки, що дає змогу студенту засвоїти техніку і подолати психологічний бар’єр першого виконання цього дослідження. Після тренінгової частини викладач змінює насадки шийки матки у фантомі, моделюючи різні види фонової патології, що дозволяє перевести звичайний тренінг у площину розв'язання проблемних ситуаційних задач. Можливості сучасного фантома до-

\section{Список літератури}

1. Алексеєнко А. П. Філософсько-етичні виклики симуляційному навчанню в медицині / А. П. Алексеєнко // Симуляційне навчання в системі підготовки медичних кадрів : матеріали L навч.-метод. конф., присвяченої 212-й річниці від дня заснування ХНМУ (Харків, 30 листопада 2016 р.). - Харків, 2016. - С. 63-65.

2. Загальні проблеми та перспективи застосування симуляційних методів освіти / В. М. Лісовий, В. А. Капустник, В. Д. Марковський, І. В. Завгородній // Симуляційне навчання в системі підготовки медичних кадрів : матеріали L навч.-метод. конф., присвяченої 212-й річ- зволяють також змінювати насадки матки, імітуючи певні види патології тіла матки - вагітність різних термінів, пухлини різної величини та консистенції, патологічні зміни з боку придатків. Перевагою фантомного моделювання є те, що передня черевна стінка змодельована еластичною і закритою, що позбавляє студента можливості зорового контролю і залишає йому тільки перцептивні відчуття, тобто сферу діагностики, доступну в реальному житті 3 реальними пацієнтками.

Окрім вивчення методів дослідження, фантом дає можливість демонстрації малих гінекологічних операцій викладачем для студентів, що готуються стати лікарями загальної практики, та відпрацювання їх, якщо йдеться про спеціалізацію лікарягінеколога.

Висновок. Симуляційне навчання, зокрема такий його елемент, як фантомне моделювання, $є$ технологією майбутнього, що дозволяє студентам швидко та якісно оволодіти базовим рівнем практичних навиків та умінь. Використання симуляційних програм для ускладнення завдань забезпечує формування професійних умінь, необхідних для роботи за фахом для лікаря загальної практики.

ниці від дня заснування ХНМУ (Харків, 30 листопада 2016 р.). - Харків, 2016. - С. 3-7.

3. Омельчук М. А. Методика використання симуляційного навчання у процесі формування компетентності з надання першої долікарської допомоги у провізорів / М. А. Омельчук // Вісник Черкаського університету. - 2016. - Вип. № 10. - С. 118-123.

4. Створення симуляційного центру: засади та керівні настанови. Досвід програми “Здоров’я матері та дитини” : посібник. - К. : Вістка, 2015. - 56 с.

5. The King's Midwife: A History and Mystery of Madame du Coudray, by Nina Rattner Gelbart, Berkeley: University of California Press (1998). ISBN 0-520-21036-0

Отримано 07.11.16 